\title{
Hydrolysis of the soft amphiphilic antimicrobial agent tetradecyl betainate is retarded after binding to and killing Salmonella typhimurium
}

\author{
Britta Ahlström and Lars Edebo \\ Author for correspondence: Britta Ahlström. Tel: +46 31 604729. Fax: +46 31604975 . \\ e-mail : britta.ahlstrom@microbio.gu.se
}

Department of Clinical Bacteriology, Göteborg University, Guldhedsgatan 10, S-413 46 Göteborg, Sweden

\begin{abstract}
Hydrolysis of tetradecyl betainate (B14), a fast-acting microbicidal amphiphilic quaternary ammonium compound (QAC) being an ester of betaine and tetradecanol, occurred after binding to Salmonella typhimurium, resulting in release of the water-soluble betaine portion and retention of the lipophilic tetradecanol. The rate of the hydrolysis was significant but retarded in comparison to B14 in solution. As in free solution, the hydrolysis of substance bound to $S$. typhimurium was increased in an alkaline environment and by heat. At pH 6.0 and $20^{\circ} \mathrm{C}$ the hydrolysis of bound ester was about $10 \%$ after $180 \mathrm{~min}$, whereas at $\mathrm{pH} 9.0$ and $50{ }^{\circ} \mathrm{C}$ it was about $50 \%$ after $60 \mathrm{~min}$. These results are consistent with a model where amphiphilic QACs are inserted into the bacterial outer membrane (OM) with the quaternary ammonium head group facing outwards and the lipophilic portion, including the ester bond, being in the membrane lipid environment enough for retarding the hydrolysis. However, calculation of the mean concentration of B14 in the bacteria at MBC $_{99}$ (minimum bactericidal concentration required to kill $99 \%$ of cells) showed a 7000-8000 times greater concentration than in the medium. At this concentration, when most B14 is considered to be bound to the OM, the available surface area for each molecule was only $2 \AA^{2}$. This is only $6-7 \%$ of that required for close packing of the quaternary ammonium head group (30 $\left.\AA^{2}\right)$, indicating that a three-dimensional, presumably continuous arrangement was formed. Since B14 is hydrolysed after its binding to bacteria with microbicidal effect, it may be used under conditions where stable QACs might be harmful to the close or the common environment.
\end{abstract}

Keywords: quaternary ammonium compound, alkyl betainate, hydrolysis, Salmonella typhimurium

\section{INTRODUCTION}

Soft antimicrobial agents are structural analogues of fast-acting, microbicidal substances with a labile spot introduced into the molecule allowing them to degrade into innocuous substances (Bodor et al., 1980). We have studied the antimicrobial action and hydrolysis of amphiphilic alkyl betaine esters (Edebo et al., 1992; Lindstedt et al., 1990; Thompson et al., 1990) which are quaternary ammonium compounds (QACs). Their anti-

Abbreviations: $B 14$, tetradecyl betainate; $C T A B$, hexadecyltrimethylammonium bromide; OM, outer membrane; $Q A C$, quaternary ammonium compound. microbial action is similar to corresponding, wellestablished QAC disinfectants like monoalkyltrimethylammonium halides (e.g. cetyltrimethylammonium bromide, Cetavlon), but they hydrolyse spontaneously into betaine and fatty alcohol that are readily metabolized. Our previous studies have shown that their hydrolysis is enhanced at higher $\mathrm{pH}$ and in micellar aggregates (Lindstedt et al., 1990; Thompson \& Allenmark, 1989) and reduced at higher ionic strength and in aggregates with fatty acids and fatty alcohol (Thompson \& Allenmark, 1992). These results support the hypothesis that the hydrolysis is facilitated by the presence of hydroxide ions in the vicinity of the ester bond. Since the microbicidal action of QACs is considered to involve 
(a)

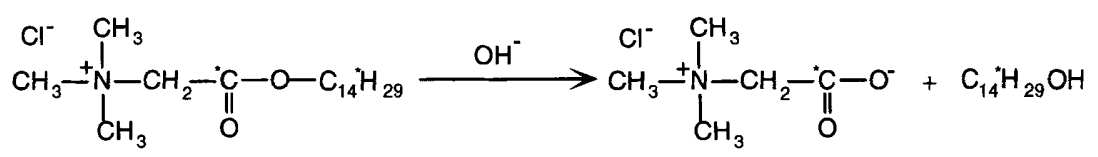

(b)<smiles>C[N+](C)(C)c1ccccc1</smiles>

Fig. 1. (a) Hydrolysis scheme for duallabelled $\left[{ }^{3} \mathrm{H},{ }^{14} \mathrm{C}\right] \mathrm{B} 14$. (b) Structure of singlelabelled $\left[{ }^{3} \mathrm{H}\right] \mathrm{CTAB}$. intercalation of QAC molecules into cell membrane(s) with charge and hydrophobic interaction with lipid bilayer constituents, the close environment of the ester bond will be changed in the binding process. This study was undertaken to investigate the effect of binding of tetradecyl betainate to Salmonella typhimurium on its rate of hydrolysis.

\section{METHODS}

Chemicals. The procedures for synthesis of tetradecyl betainate chloride (B14) and $\left[{ }^{3} \mathrm{H},{ }^{14} \mathrm{C}\right] \mathrm{B} 14$ (Fig. 1a) were slight modifications of versions described by Thompson et al. (1990). ${ }^{14} \mathrm{C}$ was incorporated in the betaine portion and ${ }^{3} \mathrm{H}$ in the tetradecanol. The radiochemical purity of the products was verified by HPLC with on-line $\beta$-radioactivity detection. All products were found to have $>99 \%$ radiochemical purity. Hexadecyltrimethylammonium bromide (CTAB) was obtained from Fluka (purity $98 \%$ ). The synthesis of $\left[{ }^{3} \mathrm{H}\right] \mathrm{CTAB}$ (Fig. 1b), with ${ }^{3} \mathrm{H}$ incorporated in the polar portion was described by Thompson \& Allenmark (1992).

Instrumentation and chromatography. The radiochromatography system used in this study was composed of an LKB model $2150 / 2152$ dual pump gradient delivery system, a $500 \mu \mathrm{l}$ loop, an analytical $(4.6 \times 150 \mathrm{~mm})$ column packed with $7 \mu \mathrm{m}$ Nucleosil C-18 and a Radiomatic A-250 radioactivity monitor. The detector was equipped with a $500 \mu$ liquid scintillation cell and the scintillator fluid/mobile phase flow rate ratio was $4: 1$. The mobile phase consisted of $50 \%(\mathrm{v} / \mathrm{v})$ acetonitrile in water, adjusted to $\mathrm{pH} 3.0$ with $\mathrm{HCl}$, with a flow rate of $1 \mathrm{ml}$ $\min ^{-1}$. The liquid scintillation counter was an LKB 1217 instrument.

Bacterial strains and growth conditions. Salmonella typhimurium 395 MS (serogroup B, S form) and Salmonella typhimurium $395 \mathrm{R} 10$ (chemotype $\mathrm{Rd}$ mutant) have been described previously (Edebo et al., 1980). The bacteria were maintained by monthly subculture on nutrient agar plates and kept at $4{ }^{\circ} \mathrm{C}$. For use in the tests, the bacteria were cultured in glucose broth $\left(\mathrm{g} \mathrm{l}^{-1}\right.$ in distilled water: Bacto peptone, 10; Difco beef extract, 5; $\mathrm{Na}_{2} \mathrm{HPO}_{4} .2 \mathrm{H}_{2} \mathrm{O}, 0 \cdot 6 ; \mathrm{NaCl}, 1 \cdot 8$; glucose, 1) at $\mathrm{pH} 7 \cdot 0-7 \cdot 2$ for $16 \mathrm{~h}$ at $37^{\circ} \mathrm{C}$ on a rotary shaker (200 r.p.m.), harvested by centrifugation, washed once with PBS and finally resuspended in $0.01 \mathrm{M}$ phosphate buffer, $\mathrm{pH} 7 \cdot 0$. This bacterial stock suspension contained about $1.5 \times 10^{10}$ c.f.u. $\mathrm{ml}^{-1}\left(10 \mathrm{~g}\right.$ dry mass $\left.\mathrm{l}^{-1}\right)$.

Binding of QACs. A volume of $100 \mu \mathrm{l}$ bacterial stock suspension was mixed with $900 \mu \mathrm{l}$ of different concentrations of radiolabelled compounds in $0 \cdot 01 \mathrm{M}$ phosphate buffer, $\mathrm{pH} 7 \cdot 0$, at $20{ }^{\circ} \mathrm{C}$. After $10 \mathrm{~min}$ the bacteria were sedimented by centrifugation at 12500 r.p.m. (9000 g, Beckman Microfuge E) for $5 \mathrm{~min}$ and the radioactivity in the supernatant was measured with a liquid scintillation counter. After this first binding step the results with ${ }^{3} \mathrm{H}$ and ${ }^{14} \mathrm{C}$ agreed well, indicating that no significant hydrolysis had occurred $(<3 \%)$. Since higher counts were recorded for ${ }^{3} \mathrm{H}$ they are given in Figs 2 and 3. Furthermore, separation of ester, betaine and tetradecanol by HPLC with on-line radioactivity detection was performed. For HPLC analysis the hydrolysis was stopped by adding $20 \mu \mathrm{l}$ $3 \mathrm{M} \mathrm{HCl}$ to each $1 \mathrm{ml}$ of sample.

Hydrolysis of bound substance. The pelleted bacteria were resuspended in $975 \mu \mathrm{l} 0.01 \mathrm{M}$ phosphate buffer, $\mathrm{pH} 6.0$ or $9 \cdot 0$. Since B14 dissolved in the liquid medium was below $0.01 \mathrm{mM}$ (Fig. 3) at total concentrations of $0.27 \mathrm{mM}$ and below, carryover by extracellular liquid in the pellet has not been considered. The suspension was transferred to glass tubes and incubated at 20,37 and $50{ }^{\circ} \mathrm{C}$ for different periods of time, transferred back to Eppendorf tubes and centrifuged again. The pelleted bacteria were finally resuspended in $60 \%(\mathrm{v} / \mathrm{v})$ methanol to extract bound substance. ${ }^{3} \mathrm{H}$ and ${ }^{14} \mathrm{C}$ in the supernatants and bacterial suspensions were measured as described above and the recovery calculated.

At temperatures of $37^{\circ} \mathrm{C}$ and above the substance bound to the walls of the Eppendorf centrifuge tubes. To minimize this effect, glass tubes were used during tests on hydrolysis. Substance bound to the tube walls was determined after extraction with $60 \%$ methanol.

Bactericidal activity of B14. From the washed stock suspension, $100 \mu$ l portions of $S$. typhimurium R10 were mixed with serial dilutions of B14 in $0.01 \mathrm{M}$ phosphate buffer, $\mathrm{pH} 7 \cdot 0$, and kept at $20^{\circ} \mathrm{C}$ for $10 \mathrm{~min}$. Then samples were diluted in Letheen broth $\left[\mathrm{g} \mathrm{I}^{-1}\right.$ in distilled water: Thiotone peptone (BBL Microbiology Systems), 10.0; beef extract, $5 \cdot 0$; lecithin, $0 \cdot 7$; polysorbate $80,5 \cdot 0$; sodium chloride, $5 \cdot 0$ ] and plated onto nutrient agar plates by use of the spiral plater system (Spiral Systems). Letheen broth inactivates QACs and is used as a standard neutralizing diluent for the evaluation of disinfectants containing cationic surfactants (Association of Official Analytical Chemists, 1984). The agar plates were incubated at $37^{\circ} \mathrm{C}$ for $2 \mathrm{~d}$ and the surviving fraction calculated.

\section{RESULTS}

\section{Binding and uptake of QAC}

The binding isotherm for S. typhimurium 395 MS and $\mathrm{R} 10$, plotted as the number of bound B14 molecules (unit dry wt bacteria) ${ }^{-1}$ versus concentration of B14 remaining in solution after binding $(=$ free B14 concentration) showed that most of the added QAC was bound up to a free concentration of about $0.35 \mathrm{mM}$ (Figs 


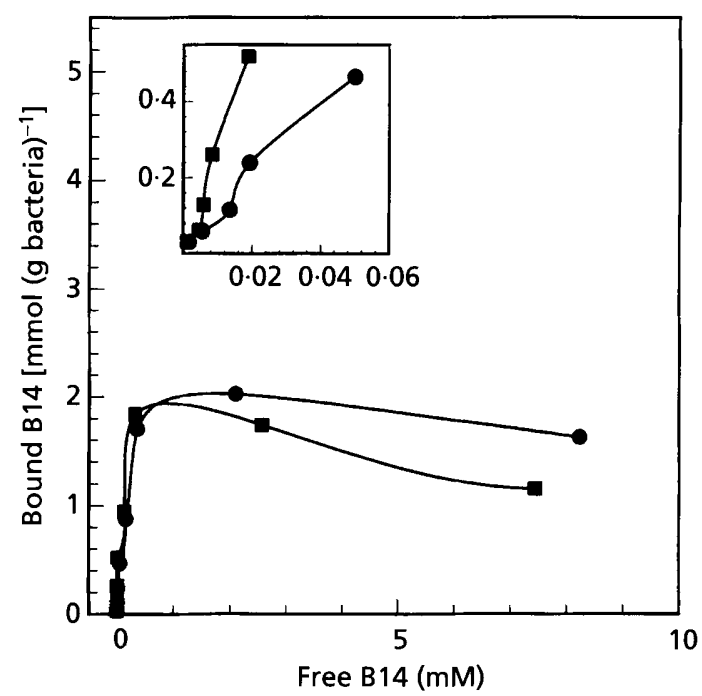

Fig. 2. Binding isotherms for the interaction of $S$. typhimurium $395 \mathrm{MS}(\mathbf{0})$ and $\mathrm{R} 10(\boldsymbol{\square})$ with $\mathrm{B} 14$ at $\mathrm{pH} 7.0$ and $20^{\circ} \mathrm{C} .{ }^{3} \mathrm{H}$ was incorporated in the hydrophobic portion (hydrocarbon) of the molecule. The insert shows an expansion of the abscissa in the range $0.01-0.06 \mathrm{mM}$.

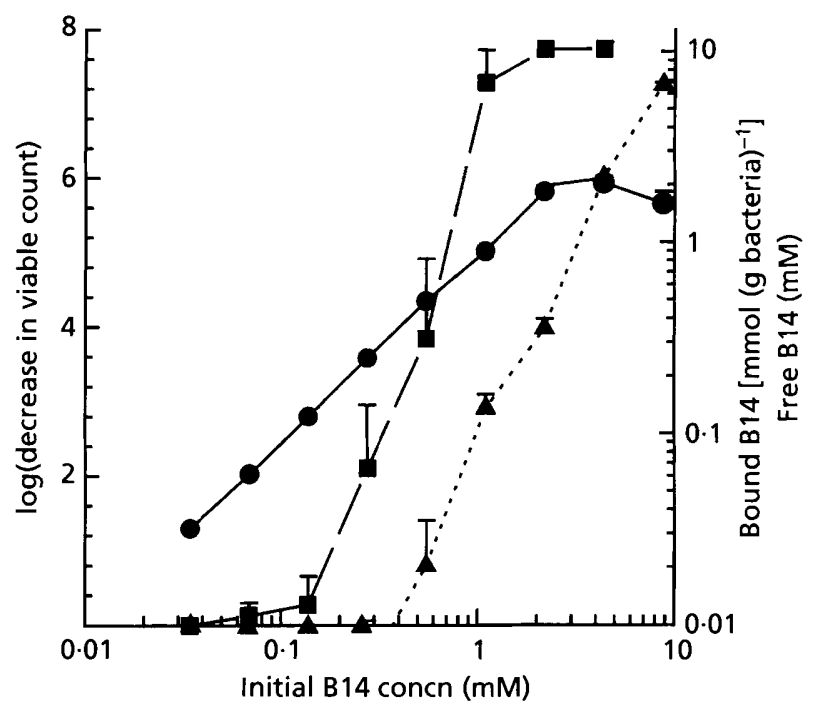

Fig. 3. Binding of B14 and killing of $S$. typhimurium $395 \mathrm{R} 10$ $\left(1.5 \times 10^{9}\right.$ c.f.u. $\left.\mathrm{ml}^{-1}\right)$ at $\mathrm{pH} 7.0$ and $20^{\circ} \mathrm{C}$ for $10 \mathrm{~min}$. 0 , Bound B14; $\Delta$, free B14 in supernatant; $\boldsymbol{a}$, dead bacteria shown as $\log$ (decrease in viable count) (limit of detection 20 c.f.u. $\mathrm{ml}^{-1}$ ).

2 and 3). This was true for both strains MS and R10. At higher concentrations the bound B14 remained constant or decreased slightly (Fig. 2). At low concentrations of B14 more bound to strain R10 than to MS (Fig. 2 insert), whereas the reverse was found at higher concentrations.

\section{The bactericidal effect in relation to binding}

For $99 \%$ killing of S. typhimurium R10, about $0.27 \mathrm{mM}$ $\left(0 \cdot 1 \mathrm{~g}^{-1}\right) \mathrm{B} 14$ was required and at $1 \mathrm{mM}$ the killing was almost total (Fig. 3). The maximum killing effect was

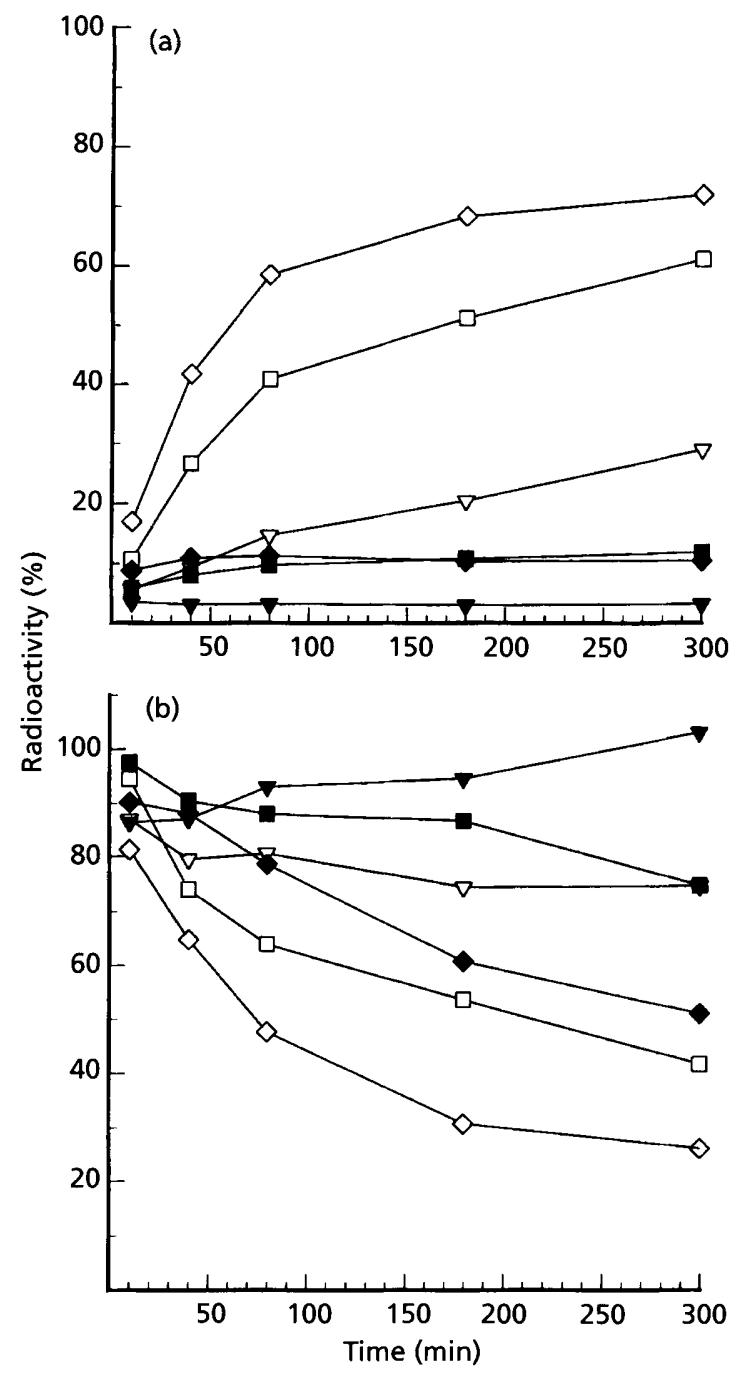

Fig. 4. S. typhimurium $395 \mathrm{R} 10\left(1.5 \times 10^{9}\right.$ c.f.u. $\left.\mathrm{ml}^{-1}\right)$ was exposed for $10 \mathrm{~min}$ at $20^{\circ} \mathrm{C}$ to $0.27 \mathrm{mM}$ B14 labelled in both the betaine $\left({ }^{14} \mathrm{C}\right.$, open symbols) and tetradecanol $\left({ }^{3} \mathrm{H}\right.$, filled symbols) portions. The bacteria were centrifuged, resuspended in buffer at $\mathrm{pH} 9.0$, incubated at $20(\nabla, \nabla), 37(\square, \square)$ and $50^{\circ} \mathrm{C}$ $(\diamond, \diamond)$ for different periods of time and centrifuged again. Radioactivity was measured in the supernatant (a) and in the methanol extract from the remaining bacteria (b) and calculated as a percentage of the amount bound.

attained when the binding capacity for B14 was saturated (Fig. 3). At the $99 \%$ killing effect nearly all the B14 $(0.27 \mathrm{mM})$ was bound to the bacteria. These conditions were chosen for studying the hydrolysis of bound substance.

\section{Hydrolysis of bound substance}

Bacteria were exposed to $0.27 \mathrm{mM} \mathrm{B} 14$ at $20^{\circ} \mathrm{C}$ for $10 \mathrm{~min}$, centrifuged, resuspended in buffer, $\mathrm{pH} 9 \cdot 0$, and further incubated at 20,37 and $50^{\circ} \mathrm{C}$ for different lengths of time. It was evident that the release of ${ }^{14} \mathrm{C}$ (betaine portion) proceeded fairly rapidly, particularly at higher temperatures, whereas ${ }^{3} \mathrm{H}$ (tetradecanol portion) remained with the bacteria (Fig. 4a). Hydrolysis 
(a)

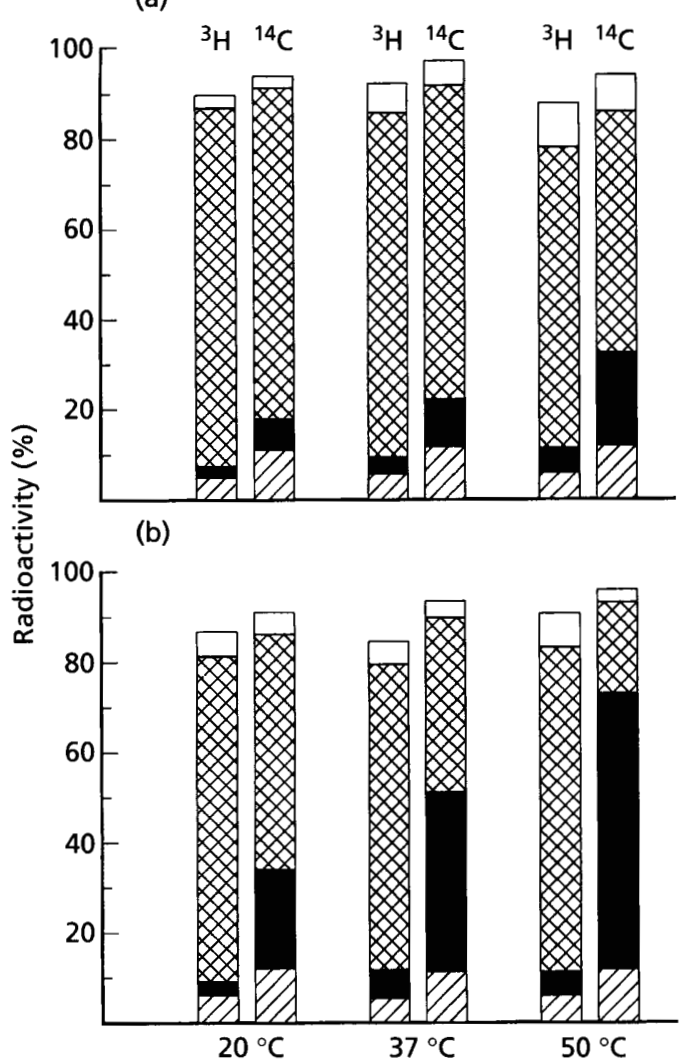

Fig. 5. S. typhimurium $395 \mathrm{R} 10\left(1.5 \times 10^{9}\right.$ c.f.u. $\left.\mathrm{ml}^{-1}\right)$ was exposed to $0.27 \mathrm{mM} \mathrm{B14}$, centrifuged and resuspended in buffer at pH 6.0 (a) or 9.0 (b). $叉$, Supernatant from bacteria exposed to B14 for $10 \mathrm{~min}$; $\square$, release from bacteria after resuspension and incubation at the indicated temperature for $180 \mathrm{~min}$; 8 , methanol extract from remaining bacteria; $\square$, extract from glass tube.

was observed after $1 \mathrm{~min}$ incubation at 37 and $50{ }^{\circ} \mathrm{C}$. After about $60 \mathrm{~min}$ at $50^{\circ} \mathrm{C}, 50 \%$ of the $\mathrm{B} 14$ was recovered as hydrolysed product in the medium; this increased to $70 \%$ after $180 \mathrm{~min}$. At $37^{\circ} \mathrm{C}$ the hydrolysis resembled that observed at $50{ }^{\circ} \mathrm{C}$ but proceeded at a lower velocity. The proportion of ${ }^{3} \mathrm{H}$ in the supernatant never exceeded $10 \%$ (Fig. 4a). Most of the remaining radioactivity was released by methanol treatment of the pelleted bacteria. This extract contained most of the initially bound ${ }^{3} \mathrm{H}$, but there was a reduction in ${ }^{14} \mathrm{C}$ corresponding to the proportion released such that the total recovery was close to $100 \%$. However, samples incubated at $50{ }^{\circ} \mathrm{C}$ for $180 \mathrm{~min}$ and longer lost about $30 \%$ total ${ }^{3} \mathrm{H}$ activity (Fig. $4 \mathrm{~b}$ ). Some of the missing ${ }^{3} \mathrm{H}$ could be extracted from the glass tube (Figs 5-9).

The fate of B14 and its hydrolysis products was further tested by exposing S. typhimurium R10 to $0 \cdot 27 \mathrm{mM}$ B14 for $10 \mathrm{~min}$ at $20^{\circ} \mathrm{C}$, centrifuging and resuspending the bacteria in buffer at $\mathrm{pH} 6.0$ and 9.0 for incubation at 20 , 37 and $50{ }^{\circ} \mathrm{C}$ for $180 \mathrm{~min} .{ }^{3} \mathrm{H}$ and ${ }^{14} \mathrm{C}$ were measured in (i) the first supernatant after the bacteria had been

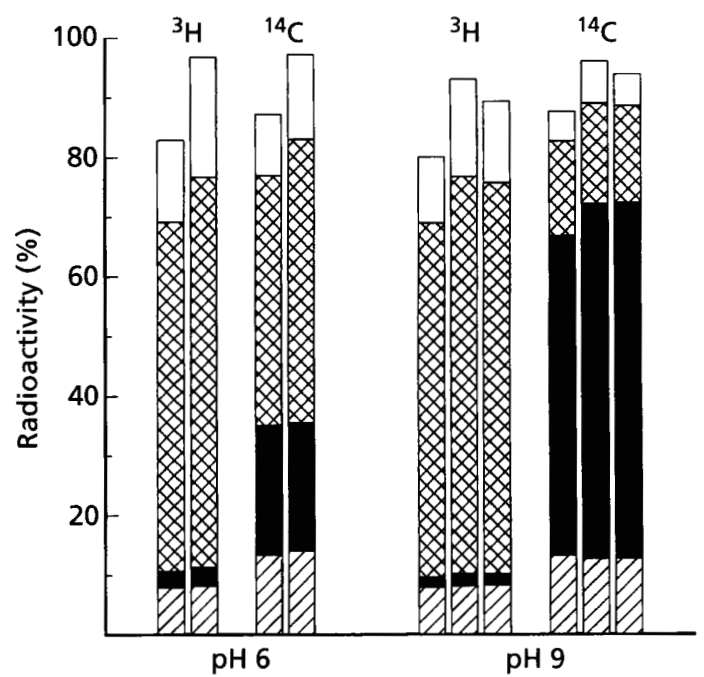

Fig. 6. Reproducibility and effect of B14 concentration on hydrolysis of $0.55 \mathrm{mM}$ B14 bound to S. typhimurium $395 \mathrm{R} 10$ $\left(1.5 \times 10^{9}\right.$ c.f.u. $\left.\mathrm{ml}^{-1}\right)$. $\$, Supernatant from bacteria exposed to $\mathrm{B} 14$ for $10 \mathrm{~min}$; , release from bacteria after resuspension and incubation at $50^{\circ} \mathrm{C}$ for $180 \mathrm{~min}$; 8 , methanol extract from remaining bacteria; $\square$, extract from glass tube.

exposed to B14 for $10 \mathrm{~min}$, (ii) the second supernatant after resuspension, incubation for $180 \mathrm{~min}$ and centrifugation, (iii) a methanol extract from the bacteria and (iv) a methanol extract from the glass tubes (Fig. 5). After mixing at $20^{\circ} \mathrm{C}$ for $10 \mathrm{~min}$, a greater proportion of ${ }^{14} \mathrm{C}$ than ${ }^{3} \mathrm{H}$ was released, indicating liberation of the betaine portion of the molecule. When bacteria with bound B14 were incubated for $180 \mathrm{~min}$, the liberation of ${ }^{14} \mathrm{C}$ into the medium increased with $\mathrm{pH}$ and temperature: about $60 \%$ at $\mathrm{pH} 9.0$ and $50^{\circ} \mathrm{C}$ but only about $20 \%$ at $20^{\circ} \mathrm{C}$ and $20 \%$ also at $\mathrm{pH} 6.0$ and $50{ }^{\circ} \mathrm{C}$ (Fig. 5). These results were reproducible and the recovery of added radioactivity was $\geqslant 90 \%$ for ${ }^{14} \mathrm{C}$ and $\geqslant 80 \%$ for ${ }^{3} \mathrm{H}$ (Figs 5 and 6 ). Doubling the concentration of B14 $(0.55 \mathrm{mM})$ did not affect the hydrolysis rate (Fig. 6). Around $60-70 \%$ of bound substance was also hydrolysed at $\mathrm{pH} 9.0$ and $50^{\circ} \mathrm{C}$ after $180 \mathrm{~min}$ with $0.5 \mathrm{mmol} \mathrm{B14}$ bound (g bacteria) ${ }^{-1}$ (Figs 3 and 6).

To ascertain the identity of the radioactive compounds and quantify binding as well as hydrolysis, the radioactivity of supernatants and of methanol extracts of bacteria was measured after separation into B14, betaine and tetradecanol by HPLC with on-line radioactivity detection. The results confirmed that most of the ${ }^{14} \mathrm{C}$ released into the supernatant was betaine. However, some betaine appeared to be retained in the bacteria at $\mathrm{pH} 6$ and was extracted with methanol. Not all the ${ }^{14} \mathrm{C}$ found in the soluble fraction without separation (Fig. $7 a)$ could be recovered in the separated fraction (Fig. 7b), which might be due to low counts in the HPLC fractions. The other part of the molecule, tetradecanol $\left({ }^{3} \mathrm{H}\right)$, was extracted by methanol, as was B14 (Fig. 7b).

To compare the binding of B14 with that of a traditional 
(a)

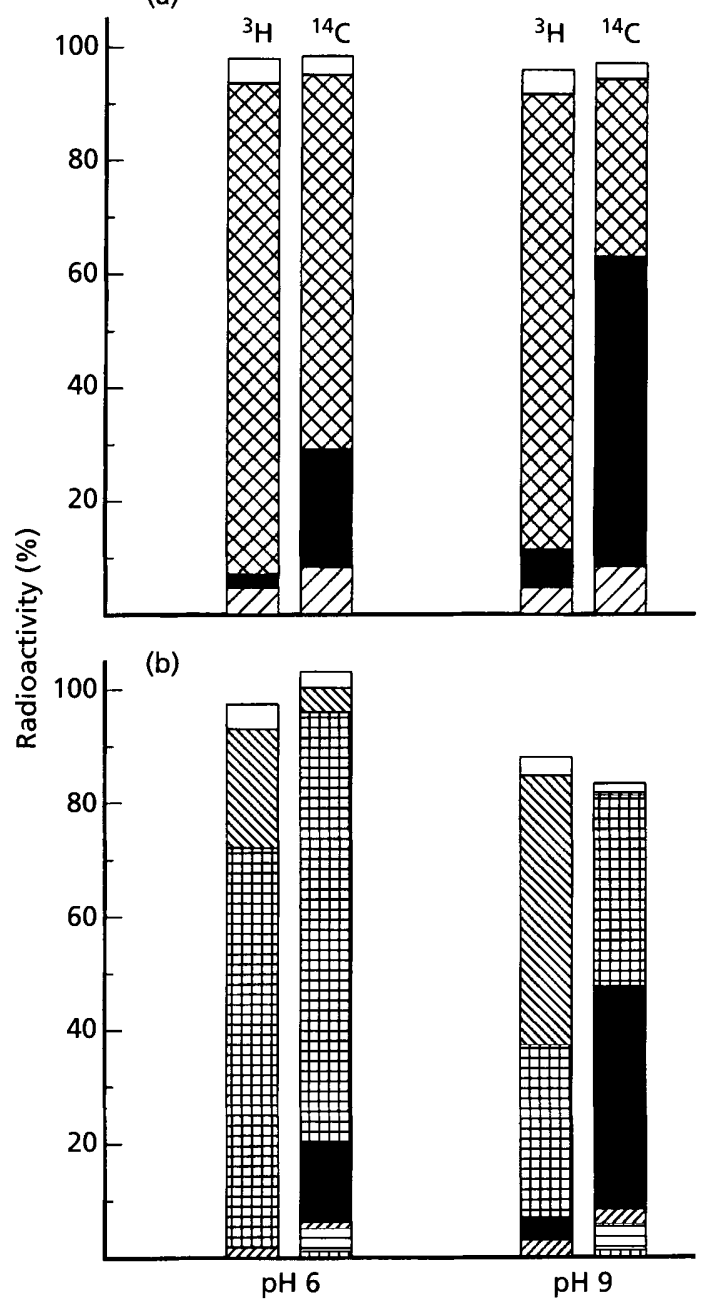

Fig. 7. S. typhimurium 395 R10 $\left(2.8 \times 10^{9}\right.$ c.f.u. $\left.\mathrm{ml}^{-1}\right)$ was exposed to $0.55 \mathrm{mM} \mathrm{B14}$, centrifuged and resuspended in buffer at $\mathrm{pH} 6.0$ or 9.0 . (a) Total radioactivity measured with a liquid scintillation counter. $\square$, Supernatant from bacteria exposed to B14 for $10 \mathrm{~min}$; release from bacteria after resuspension and incubation at $50^{\circ} \mathrm{C}$ for $180 \mathrm{~min}$; 8 , methanol extract from remaining bacteria; $\square$, extract from glass tube. (b) Radioactivity measured after separation of B14, betaine and tetradecanol by HPLC with on-line detection. B14 $(\mathbb{D})$ or tetradecanol $\left({ }^{3} \mathrm{H}\right)$ or betaine $\left({ }^{14} \mathrm{C}\right)(\mathrm{G})$ in supernatant after $10 \mathrm{~min}$ of binding; release of B14 (B), or tetradecanol $\left({ }^{3} \mathrm{H}\right)$ or betaine $\left({ }^{14} \mathrm{C}\right)(\mathbf{0})$ from bacteria after resuspension and incubation at $50^{\circ} \mathrm{C}$ for $180 \mathrm{~min}$; methanol-extracted B14 (眏), or tetradecanol $\left({ }^{3} \mathrm{H}\right)$ or betaine $\left({ }^{14} \mathrm{C}\right)(\mathbb{\nabla})$ from remaining bacteria; $\square$, tetradecanol $\left({ }^{3} \mathrm{H}\right)$ or betaine $\left({ }^{14} \mathrm{C}\right)$ extracted from glass tube.

non-ester QAC and check whether the reaction mechanisms in the Rd mutant, R10, also occur in wild-type strains, S. typhimurium MS was exposed to $0.27 \mathrm{mM}$ $\mathrm{B} 14\left(0 \cdot 1 \mathrm{~g} \mathrm{l}^{-1}\right)$ or $0 \cdot 26 \mathrm{mM} \mathrm{CTAB}\left(0 \cdot 1 \mathrm{~g} \mathrm{l}^{-1}\right)$ for $10 \mathrm{~min}$ at $20^{\circ} \mathrm{C}$ and centrifuged. CTAB bound to the bacteria at least as much as B14 (Fig. 8a, b). For CTAB only $5 \%$ was found in the first supernatant and the same amount or less in the second supernatant, slightly more at higher than at lower temperatures with almost no effect of $\mathrm{pH}$. (a)

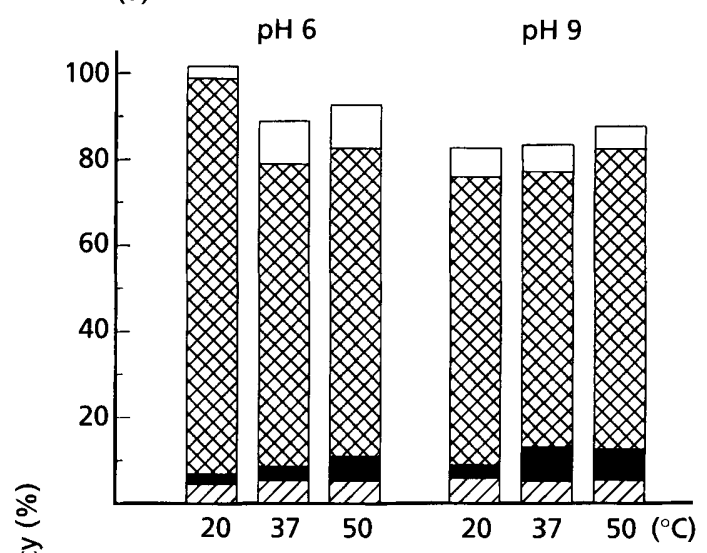

(b)

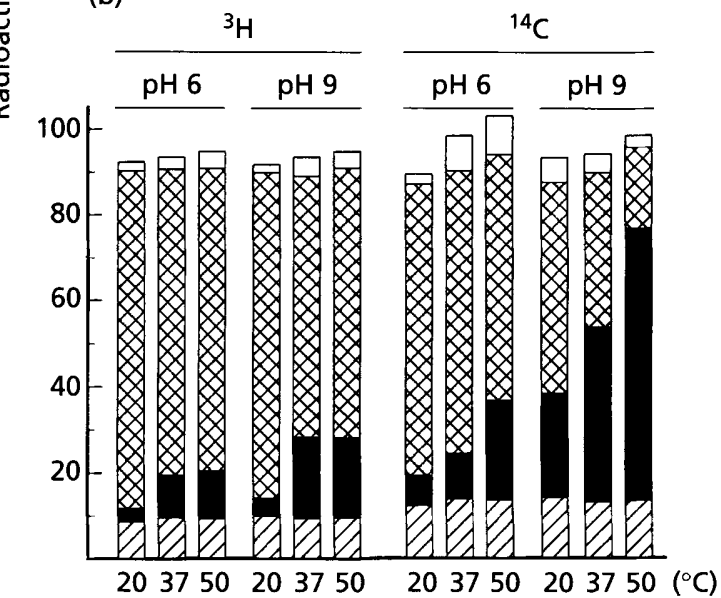

Fig. 8. S. typhimurium $395 \mathrm{MS}\left(1.5 \times 10^{9}\right.$ c.f.u. $\left.\mathrm{ml}^{-1}\right)$ was exposed to $0.26 \mathrm{mM} \mathrm{CTAB} \mathrm{(a)} \mathrm{or} 0.27 \mathrm{mM}$ B14 (b) for $10 \mathrm{~min}$, centrifuged and resuspended in buffer at $\mathrm{pH} 6.0$ or 9.0 . The radioactivity was present in the betaine portion of $B 14$. Supernatant from bacteria exposed to QAC for $10 \mathrm{~min}$; release from bacteria after resuspension and incubation at the indicated temperature for $180 \mathrm{~min}$; 8 , methanol extract from remaining bacteria; $\square$, extract from glass tube.

Nearly all the radioactivity was recovered from the pellet (Fig. 8a). The proportion of betaine $\left({ }^{14} \mathrm{C}\right)$ and tetradecanol $\left({ }^{3} \mathrm{H}\right)$ released from S. typhimurium MS (Fig. 8b) was in the same range as for S. typhimurium R10 (Fig. 5b).

The stable compound CTAB bound in a similar way to the smooth S. typhimurium MS and to the more hydrophobic strain R10. For strain R10 almost no increased release at elevated temperature was observed (Fig. 9). Binding of $\left[{ }^{3} \mathrm{H}\right]$ tetradecanol to $S$. typhimurium $\mathrm{R} 10$ was nearly complete, whereas it was only $50 \%$ to strain MS (not shown).

\section{DISCUSSION}

It has long been known that the hydrolysis of short chain alkyl esters (methyl and ethyl) of betaine is favoured by hydroxide ions and higher temperatures (Robson 


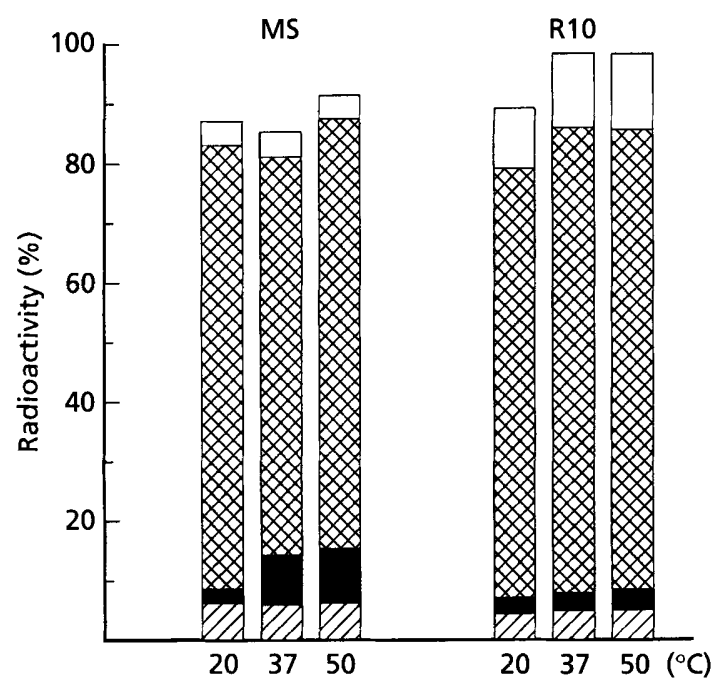

Fig. 9. S. typhimurium $395 \mathrm{MS}$ and $\mathrm{R} 10\left(1.5 \times 10^{9}\right.$ c.f.u. $\left.\mathrm{ml}^{-1}\right)$ were exposed to $0.26 \mathrm{mM}$ CTAB for $10 \mathrm{~min}$, centrifuged and resuspended in buffer at $\mathrm{pH} 9.0$. Supernatant from bacteria exposed to $C T A B$ for $10 \mathrm{~min}$; $\boldsymbol{\square}$, release from bacteria after resuspension and incubation at the indicated temperature for $180 \mathrm{~min}$; $\$$, methanol extract from remaining bacteria; $\square$, extract from glass tube.

Wright, 1968). This is also true for esters with longer hydrocarbon chains, i.e. $\mathrm{C}_{10}-\mathrm{C}_{18}$ (Lindstedt et al., 1990; Thompson \& Allenmark, 1989). Furthermore, the hydrolysis rate of the latter substances was enhanced at higher concentrations reaching a maximum close to critical micelle concentration (CMC), suggesting micellar catalysis of autohydrolysis. The favoured interpretation is that cationic micelles attract hydroxide ions, resulting in an alkaline microenvironment. In contrast, increased ionic strength and anionic amphiphilic compounds antagonize the hydrolysis (Thompson \& Allenmark, 1992), probably by shielding the access of hydroxide ions. It has also been shown that amphiphilic betaine esters bind to the outer membrane (OM) and cytoplasmic membrane of enterobacteria and effect rapid membrane permeation (Ahlström \& Edebo, 1994) and exert a bactericidal effect (Lindstedt et al., 1990). Thus, it might be anticipated that their binding to bacteria would influence the hydrolysis of amphiphilic betaine esters.

The binding of B14 to the bacteria was rapid and efficient. Similar binding kinetics were recorded for the parent S strain, S. typhimurium 395 MS, and its Rd mutant, R10 (Figs 2 and 3). Somewhat greater binding to strain R10 than to MS was recorded at lower concentrations (Fig. 2, insert), probably as a consequence of the greater hydrophobicity and anionic character of strain R10 (Edebo et al., 1980) which should favour the binding of the amphiphilic and cationic B14. The presence of the hydrophilic group B O-antigen polysaccharide side chain in strain MS might also interfere with initial binding of B14. However, at higher concentrations of $\mathrm{B} 14$, the order of the binding capacity was reversed and slightly greater to strain MS, indicating that the general conclusions are relevant for a wide range of enterobacteria.

That the binding of B14 to strain R10 increased linearly with concentration up to $2 \cdot 2 \mathrm{mM}$ appears more clearly in Fig. $3\left(r^{2}=0.9993\right)$. A killing effect of $99 \%$ was achieved when $0.27 \mathrm{mM} \mathrm{B} 14$ was acting on the bacteria. In this case less than $0.01 \mathrm{mM} \mathrm{B} 14(0.008 \mathrm{mM})$ remained in the medium and the binding to strain R10 was about 0.25 mmol B14 (g dry wt bacteria) ${ }^{-1}$. Since the water content in Escherichia coli has been estimated as $70 \%$ of its wet weight (Neidhardt, 1987) the volume of bacteria in $\mathrm{ml}$ is taken as four times the dry weight in $\mathrm{g}$, implying that the mean concentration of B14 in the bacteria was $0.0625 \mathrm{M}$, i.e. $7000-8000$ times that in the medium. At the minimum bactericidal concentration the periplasmic enzyme $\beta$-lactamase, but not the cytoplasmic enzyme $\beta$ galactosidase, leaks from $E$. coli $\mathrm{K}-12$ cells (Ahlström \& Edebo, 1994), implying that damage was caused to the OM but not to the cytoplasmic membrane. Presumably most of the QAC was bound to the OM at this stage; this is even more likely at $0.14 \mathrm{mM} \mathrm{B} 14$ when about $30 \%$ of the bacteria were killed. If the surface area of a bacterium is taken as $4 \mu \mathrm{m}^{2}$ (Vitzthum \& Rupprecht, 1990), each B14 molecule would be allotted about 4 or $8 \AA^{2}$ at 0.27 or $0.14 \mathrm{mM}$, respectively. Since stationaryphase bacteria were used, the surface area of the bacteria would have tended to be smaller and the crowding of the QAC molecules greater. The transection area of the cationic trimethylammonium head of the QAC molecule, which is supposed to face outwards after QAC binding to membranes, is 25-30 $\AA^{2}$ (Salton, 1951; Rennie et al., 1990). Consequently there is not enough room for the QAC molecules at the OM surface plane, as shown for E. coli (Salt \& Wiseman, 1970). This is further emphasized by the presence of OM components which are negatively charged and inclined to form mixed aggregates with QAC (Thompson \& Allenmark, 1992). Due to the cone shape of QAC molecules, B14 might distort the $\mathrm{OM}$ into a three-dimensional arrangement, similar to the proposed minimal surface curved lipid bilayer model of membranes, such that holes appear resulting in leakage (Andersson et al., 1988). The distortion tendency inferred by the cone effect due to the larger dimension of the cationic heads of QAC molecules compared to the hydrocarbon tails might be restricted by the anchoring of the $O M$ to the peptidoglycan Braun layer (Braun et al., 1973). Whether the crowding in the OM forces its native constituents mixed with QAC into blebs and vesicles is not completely known. The maximum amount of B14 bound, $2 \mathrm{mmol}$ (g bacteria) ${ }^{-1}$ (Figs 2 and 3), would, if the volume was set at four times the dry weight, be $0.5 \mathrm{mmol} \mathrm{ml}^{-1}$, i.e. $0.5 \mathrm{M}$.

Incubation of double-labelled $\left[{ }^{3} \mathrm{H},{ }^{14} \mathrm{C}\right] \mathrm{B} 14$ with $S$. typhimurium $\mathrm{R} 10$ resulted in the release of ${ }^{14} \mathrm{C}$ but not ${ }^{3} \mathrm{H}$ with time, showing that most of the betaine (Figs 4a and $7 \mathrm{~b}$ ) but not the tetradecanol was released from the bacteria by hydrolysis (Fig. 4a). Betaine is very watersoluble and when the betaine ester B14 becomes inserted in the OM, the betaine portion of the molecule, which is 
considered to be oriented towards the exterior, will promote hydrolysis of B14 and liberation of betaine. In contrast, tetradecanol, which is lipophilic, remains attached to the bacteria, probably by hydrophobic interaction in the OM. The hydrolysis rate of B14 bound to bacteria, measured as the release of ${ }^{14} \mathrm{C}$, increased with temperature (Fig. 4a) and $\mathrm{pH}$ (Figs 5-8), similar to B14 in solution. At $\mathrm{pH} 9.0$ and $50{ }^{\circ} \mathrm{C}, 50 \%$ was hydrolysed during the first hour, reaching only $80 \%$ after $5 \mathrm{~h}$. These rates are much slower than in solution, where at $\mathrm{pH} 9 \cdot 0,90 \%$ was hydrolysed in less than $5 \mathrm{~min}$ (Lindstedt et al., 1990). The reduction of the hydrolysis rate might be caused by the ester bond of B14 being hidden in a complex within the $\mathrm{OM}$ or otherwise protected from hydroxide ions. It has been found that complexing with fatty alcohol or fatty acid greatly reduces the hydrolysis rate (Thompson \& Allenmark, 1992). A higher local concentration of protons at the cytoplasmic membrane due to the proton motive force (Mitchell, 1966) might contribute to retardation of B14 hydrolysis. However, at $0.27 \mathrm{mM}$ B14, only a small amount bound at the cytoplasmic membrane. Furthermore, since only $80 \%$ was hydrolysed after $5 \mathrm{~h}$, the remaining fraction of B14 might be sequestered and protected from hydrolysis.

At $\mathrm{pH} 6.0$ the rate of hydrolysis of free $\mathrm{B} 14$ at $30^{\circ} \mathrm{C}$ in $0.05 \mathrm{M}$ phosphate buffer has been estimated to be around $15 \%$ after $18 \mathrm{~h}$ (Lindstedt et al., 1990), whereas the hydrolysis of bound B14 after $3 \mathrm{~h}$ amounted to $4 \%$ at $20^{\circ} \mathrm{C}$ and $7 \%$ at $37^{\circ} \mathrm{C}$ (Fig. 5), indicating no reduction of hydrolysis at this $\mathrm{pH}$. This might be due to an effect on the microenvironment of the bacteria (Thompson \& Allenmark, 1989) since at lower $\mathrm{pH}$ charge interaction would be weaker as the negative charge of the bacterial surface is reduced. These experiments were facilitated by the strong binding of B14 and tetradecanol to the bacteria and the release of betaine which was confirmed after separation of ester, betaine and tetradecanol by HPLC with on-line detection (Fig. 7b). Only a small amount of betaine was retained in the bacteria at $\mathrm{pH} 6.0$ and this was extracted with methanol.

Studies with the stable QAC, CTAB, support the conclusion that amphiphilic QACs bind avidly to bacteria at the temperatures and $\mathrm{pH}$ ranges tested (Figs 8 and 9). A slightly enhanced release of CTAB from $S$. typhimurium MS was seen at elevated temperatures, but less so at higher $\mathrm{pH}$ (Figs 8 and 9), possibly caused by dissolution of OM components. This release was greater than for strain R10 (Fig. 9) This difference might be caused by differences in the OM of the two strains. After binding of $\left[{ }^{3} \mathrm{H}\right] \mathrm{B} 14$ (Figs 5 and $8 \mathrm{~b}$ ) a similar difference between strains MS and R10 was found for ${ }^{3} \mathrm{H}$, indicating either that B14 plus tetradecanol was released with OM components more in strain MS or that hydrolysis of temporarily free $\left[{ }^{3} \mathrm{H}\right] \mathrm{B} 14$ was taking place in the medium and the binding of $\left[{ }^{3} \mathrm{H}\right]$ tetradecanol to strain MS was inferior to that of $\left[{ }^{3} \mathrm{H}\right] \mathrm{B} 14$. The binding of $\left[{ }^{3} \mathrm{H}\right]$ tetradecanol to strain R10 was close to complete, whereas binding to strain MS was about $50 \%$ (not shown). This might be a consequence of the more hydrophilic surface of strain MS (Edebo et. al., 1992) making it less accessible to hydrophobic substances such as B14 (Nikaido \& Vaara, 1987). Thus, if hydrolysis occurred only in the medium, at least half of the amount of the soluble fraction of ${ }^{14} \mathrm{C}$, i.e. betaine plus nonhydrolysed B14, should be found in the soluble fraction of ${ }^{3} \mathrm{H}$. Since soluble ${ }^{3} \mathrm{H}$ was less than half ${ }^{14} \mathrm{C}$ in most tests with strain MS (Fig. 8b), we concluded that the hydrolysis of B14 bound to bacteria was substantial.

The interaction between Gram-negative bacteria and QACs with long hydrocarbon chains is rapid and the time needed for killing is short. The main targets for QACs are the lipid bilayers of both the outer and plasma membranes (Ahlström \& Edebo, 1994). Our results show that the QAC tetradecyl betainate interacts with bacterial outer and cytoplasmic membranes, exerts its bactericidal effect and becomes hydrolysed. Consequently, soft QACs like B14 may be used under conditions when stable QACs like CTAB might be harmful to the close or the common environment.

\section{ACKNOWLEDGEMENTS}

Grants from the Swedish Medical Research Council (Grant B96-16X-10388-04A) and the Ingabritt and Arne Lundberg Research Foundation (Grant 128/92) are gratefully acknowledged.

\section{REFERENCES}

Ahlström, B. \& Edebo, L. (1994). Selective release of the periplasmic enzyme $\beta$-lactamase from Escherichia coli with tetradecyl betainate. FEMS Microbiol Lett 119, 7-12.

Andersson, S., Hyde, S. T., Larsson, K. \& Lidin, S. (1988). Minimal surfaces and structures: from inorganic and metal crystals to cell membranes and biopolymers. Chem Rev 88, 221-242.

Association of Official Analytical Chemists (1984). Disinfectants. In Official Methods of Analysis, 14th edn, pp. 65-77. Arlington, VA: Association of Official Analytical Chemists.

Bodor, N., Kaminski, J. K. \& Selk, S. (1980). Soft drugs. 1. Labile quaternary ammonium salts as soft antimicrobials. J Med Chem 23, 469-474.

Braun, V., Gnirke, H., Henning, U. \& Rehn, K. (1973). Model for the structure of the shape-maintaining layer of the Escherichia coli cell envelope. J Bacteriol 114, 1264-1270.

Edebo, L., Kihlström, E., Magnusson, K.-E. \& Stendahl, O. (1980). The hydrophobic effect and charge effects in the adhesion of enterobacteria to animal cell surfaces and the influence of antibodies of different immunoglobulin classes. In Cell Adhesion and Motility: 3rd Symposium of the British Society for Cell Biology, pp. 65-101. Edited by A. S. G. Curtis \& J. D. Pitts. Cambridge: Cambridge University Press.

Edebo, L., Ahlström, B., Chelminska-Bertilsson, M., Lange, S., Lindstedt, M. \& Thompson, R. A. (1992). Betaine esters: quaternary ammonium compounds with time-limited activity. In Industrial Applications of Surfactants III, pp. 184-207. Edited by D. R. Karsa. Cambridge: Royal Society of Chemistry.

Lindstedt, M., Allenmark, S., Thompson, R. A. \& Edebo, L. (1990). Antimicrobial activity of betaine esters, quaternary ammonium amphiphiles which spontaneously hydrolyse into nontoxic components. Antimicrob Agents Chemother 43, 1949-1954. 
Mitchell, P. (1966). Chemiosmotic coupling in oxidative and photosynthetic phosphorylation. Biol Rev 41, 445-502.

Neidhardt, F. C. (1987). Chemical composition of Escherichia coli. In Escherichia coli and Salmonella typhimurium: Cellular and Molecular Biology, pp. 3-6. Edited by F. C. Neidhardt, J. L. Ingraham, K. Brooks Low, B. Magasanik, M. Schaechter \& H. E. Umbarger. Washington, DC: American Society for Microbiology.

Nikaido, H. \& Vaara, M. (1987). Outer membrane. In Escherichia coli and Salmonella typhimurium: Cellular and Molecular Biology, pp. 7-22. Edited by F. C. Neidhardt, J. L. Ingraham, K. Brooks Low, B. Magasanik, M. Schaechter \& H. E. Umbarger. Washington, DC: American Society for Microbiology.

Rennie, A. R., Lee, E. M., Simister, E. A. \& Thomas, R. K. (1990). Structure of a cationic surfactant layer at the silica-water interface. Langmuir 6, 1031-1034.

Robson Wright, M. (1968). Arrhenius parameter for the alkaline hydrolysis of esters in aqueous solution. Part III. Methyl betaine methyl ester. J Chem Soc B 5, 548-550.

Salt, W. G. \& Wiseman, D. (1970). The relation between the uptake of cetyltrimethylammonium bromide by Escherichia coli and its effects on cell growth and viability. J Pharm Pharmacol 22 261-264.
Salton, M. R. J. (1951). The adsorption of cetyltrimethylammonium bromide by bacteria, its action in releasing cellular constituents and its bactericidal effect. J Gen Microbiol 5, 391-404.

Thompson, R. A. \& Allenmark, S. (1989). Effects of molecular association on the rates of hydrolysis of long-chain alkyl betainates (alkoxycarbonyl-N,N,N-trialkylmethanaminium halides). Acta Chem Scand 43, 690-693.

Thompson, R. A. \& Allenmark, S. (1992). Factors influencing the micellar catalyzed hydrolysis of long-chain betainates. J Colloid Interface Sci 148, 241-246.

Thompson, R. A., Lindstedt, M. \& Allenmark, S. (1990). A liquid radiochromatographic method for following the synthesis and hydrolysis of a double $\left({ }^{3} \mathrm{H}^{14} \mathrm{C}\right)$ radiolabeled alkyl betainate. Anal Lett 23, 787-798.

Vitzthum, J. \& Rupprecht, H. (1990). Coadsorption of cationic surfactants and sodium ethylene diamine tetraacetate on silica surfaces and Escherichia coli. Acta Pharm Technol 36, 67-73.

Received 23 February 1998; revised 10 June 1998; accepted 17 June 1998. 